\title{
Lymphoplasmacytic hemorrhagic cystitis in dog: case report
}

\section{Cistite hemorrágica linfoplasmocitária em cão: relato de caso}

\author{
Karen Santos Março1* (D), João José da Costa Neto² (D), Suzana Akemi Tsuruta ${ }^{\circledR}$, Alisson de Souza Costa ${ }^{(1)}$, \\ Sofia Borin-Crivellenti5 iㅣ , Alessandra Aparecida Medeiros-Ronchib (1), Carolina Franchi João7 (1)
}

\begin{abstract}
Hematuria is a relatively common manifestation in dogs and cats secondary to disorders of the urinary tract, such as bacterial cystitis and urolithiasis, with its treatment being limited to the elimination of the primary cause. However, when hematuria is persistent or capable of causing significant hematological disorders, other less common causes should be investigated. A dog, pit bull, male, 12 years old, was admitted in the Hospital Veterinário da Universidade de Uberlândia (Veterinary Hospital of the Federal University of Uberlândia) with a major complaint of severe urinary bleeding 10 days ago. Laboratory tests showed normocytic and normochromic anemia, associated to intense hematuria. Ultrasound images revealed alterations compatible with chronic cystitis. Based on the results of the laboratory and imaging tests, treatments with antibiotic therapy associated to blood transfusions were started and the animal was referred for bladder biopsy. The histopathologic examination revealed lymphoplasmacytic hemorrhagic cystitis, a rare and very aggressive disease, which presents similar descriptions in human beings, but not yet described in dogs.
\end{abstract}

KEYWORDS: Canine; bladder; hematuria; chronic inflammation.

RESUMO: A hematúria é uma manifestação relativamente comum em cães e gatos quando secundária a distúrbios do trato urinário, tais como cistite bacteriana e urolitíase, sendo seu tratamento limitado à eliminação da causa primária. Entretanto, quando a hematúria é persistente ou capaz de causar distúrbios hematológicos significativos, outras causas menos comuns devem ser investigadas. Um cáo, pit bull, macho de 12 anos de idade deu entrada no Hospital Veterinário da xxx com queixa principal de acentuado sangramento urinário há 10 dias. Os exames laboratoriais mostraram anemia normocítica e normocrômica e hipoalbuminemia, associadas à proteinúria e hematúria intensa. As imagens ultrassonográficas revelaram à presença de estruturas compatíveis com coágulos sanguíneos e aumento da espessura e irregularidade da parede da bexiga, e a citologia do lavado vesical sugeriu cistite crônica. Com os resultados dos exames laboratoriais e de imagem, iniciaram-se os tratamentos com antibioticoterapia associados às transfusóes sanguíneas, e o animal foi encaminhado para a biopsia de bexiga. Durante o procedimento cirúrgico, observou-se que a parede vesical apresentava-se espessa e ricamente vascularizada, com elasticidade normal e ausência de massas ou pólipos nas faces interna e externa. O exame histopatológico revelou tratar-se de cistite hemorrágica linfoplasmocitária, uma doença rara e muito agressiva, a qual apresenta descrições semelhantes em seres humanos, mas ainda não descrita em cães.

PALAVRAS-CHAVE: Canino; bexiga; hematúria; inflamação crônica.

\section{INTRODUCTION}

Hematuria is related to diseases that affect the urinary system involving the kidneys, ureters, bladder and urethra, and also the bleeding of the genital tract. Its main causes are urinary tract infections, neoplasia, urolithiasis, trauma, coagulopathies, and vascular abnormalities (WESTROPP; DIBARTOLA, 2015).

Among these, acute cystitis is the most common cause of hematuria in dogs, and bacterial infection is the most common cause of acute cystitis, with bitches being more predisposed to infections than males (WESTROPP; DIBARTOLA, 2015).

Chronic cystitis in dogs is uncommon and generally associated with urolithiasis, and may be present in three different ways according to the pattern of inflammatory response, diffuse, follicular, and polypoid (BRESHEARS; CONFER, 2018).

'Doutoranda do programa de Pós-graduação em Ciência Animal da Faculdade de Medicina Veterinária de Araçatuba, Universidade Estadual Paulista Júlio de Mesquita filho Araçatuba (SP), Brazil.

${ }^{2}$ Médico veterinário autônomo.

${ }^{3}$ Médica veterinária e preceptora do programa de residência médico veterinária no Hospital veterinário da universidade federal de Uberlândia - Uberlândia (MG), Brazil. ${ }^{4}$ Médico Veterinário e preceptor do programa de residência médico veterinária, no Hospital Veterinário da Universidade Federal de Uberlândia - Uberlândia (MG), Brazil. ${ }^{5}$ Professora da Faculdade de Medicina Veterinária e do Programa de Pós-graduação em Ciências Veterinárias, Universidade Federal de Uberlândia - Uberlândia (MG), Brazil. ${ }^{6}$ Professora da Faculdade de Medicina Veterinária e do Programa de Pós-graduação em Ciências Veterinárias, Universidade Federal de Uberlândia - Uberlândia (MG), Brazil. ${ }^{7}$ Professora da Faculdade de Medicina Veterinária, Universidade Federal de Uberlândia - Uberlândia (MG), Brazil.

*Corresponding author: karensanmarco@gmail.com

Received: 04/08/2020. Accepted: 07/28/2020 
In the diffuse form, the mucosa is irregularly reddish and thickened, with thickening of the submucosa connective tissue, hypertrophy of the muscle layer, and infiltration of mononuclear cells and few neutrophils in the submucosa. The follicular form is associated with chronic urolithiasis, presents formation of lymphoid foci surrounded by hyperemia, hyperplastic mucosa with hyperplasia of caliciform cells, chronic lymphoplasmacytic infiltrate and fibrosis in the lamina propria. The polypoid form, in general, is also associated with urolithiasis or chronic bacterial infection, but are characterized by nodular mass formations in the mucosa, composed of connective tissue and infiltrated by neutrophils and mononuclear leukocytes (BRESHEARS; CONFER, 2018).

Besides these, another type of cystitis reported in the literature is the eosinophilic cystitis, which is also related to the chronicity of bladder inflammation mainly due to urolithiasis (FUENTEALBA; ILLANES, 2000; WALKER, 2018).

The bleeding cystitis with sterile urine in dogs, reported in the literature, usually results from the use of cyclophosphamide or, less commonly, carboplatin (BEST; FRY, 2013; MACDONALD; DICKINSON, 2014).

In humans, chronic cystitis with sterile urine varies histologically between interstitial cystitis, eosinophilic cystitis, and cystic cystitis, all presenting the same symptoms of acute bacterial cystitis, such as urgency, painful urination, macroscopic hematuria, and pelvic pain, but in general with a longer clinical course and a higher number of relapses (PACELLA et al., 2010).

The present report had the objective to describe a rare case, possibly unpublished, of hemorrhagic lymphoplasmacytic cystitis in a male dog, since no similar case was found in the consulted literature.

\section{CASE REPORT}

A 12-year-old male, pit bull dog, was seen at the Hospital Veterinário da Universidade Federal de Uberlândia with a history of intense urinary bleeding 10 days ago. At physical examination, the animal did not present alterations, except abdominal pain at palpation of the hypogastric region and presence of two nodules in the abdominal region lateral to the foreskin, reddish, of soft consistency, adhered in skin, with approximately $0.2 \mathrm{~cm}$ of diameter each.

Normocytic normochromic anemia (VG 22.3\%; VCM $65 \mu^{3}$; CHCM $32 \mathrm{~g} / \mathrm{dL}$, respectively) was observed in the CBC, with cytological aspects of evident anisocytosis and polychromasia compatible with regeneration and thrombocytosis $\left(558,000 \mathrm{~mm}^{3}\right)$, associated with intense hematuria as the only finding in urinalysis (Table 1) (SCHALM'S et al., 2000). Uroculture was not performed due to the impossibility of aseptic collection given the hematuria.

Regarding the serum biochemical tests, both creatinine concentration and the alkaline phosphatase and alanine amino transferase enzyme activities were borderline or within the species reference values (KANEKO; HARVEY; BRUSS, 2008).

Abdominal ultrasound revealed an irregular and thick internal bladder wall, with hyperechoic dispersed sediment deposited on the dorsal wall in a large amount, compatible with clots, and the presence of intense cellularity. The organ also presented acoustic shading in some points, which is suggestive of chronic cystitis.

The kidneys kept their dimensions and architecture preserved, both presenting a defined corticomedullary aspect, with hyperechoic cortical, hyperechoic pelvis with acoustic shading points, and discretely irregular diverticula (Figure 1). Prostatic hyperplasia was also observed.

In view of the findings, the animal was treated with norfloxacin $18 \mathrm{mg} / \mathrm{kg}$ every 12 hours, orally. After 6 days of treatment, the animal returned to the veterinary hospital showing intense hematuria and worsening of the general clinical picture, with aggravation of anemia (VG 12.9\%), and change of the erythrocytic picture, from normocytic normochromic with signs of regeneration to microcytic hypochromic (VCM $58.9 \mu \mathrm{m}^{3}$; CHCM $28.7 \mathrm{~g} / \mathrm{dL}$, respectively), with appearance of mild neutrophilic leukocytosis, with a regenerative left shift

Table 1. Results of the urinalysis tests.

\begin{tabular}{|c|c|c|}
\hline & Urinalysis 1 & Urinalysis 2 \\
\hline \multicolumn{3}{|c|}{ Physical examination } \\
\hline Color & Red & Red \\
\hline Smell & Sui Generis & Stinky \\
\hline Density: & 1.020 & 1.022 \\
\hline Reaction & Acid & Alkaline \\
\hline Aspect & Cloudy & Cloudy \\
\hline \multicolumn{3}{|c|}{ Abnormal Elements } \\
\hline Acetone & Neg. & Neg. \\
\hline Glucose & Neg. & Neg. \\
\hline Albumin & Pos +++ & Pos + \\
\hline Hemoglobin & Pos + & Neg. \\
\hline Biliary Pigments & Neg. & Traces \\
\hline Urobilinogen & Neg. & Neg. \\
\hline \multicolumn{3}{|c|}{ Sediment } \\
\hline Red Blood Cells & Full field & Full Field \\
\hline Cylinders & - & Granules + \\
\hline Epithelial Cells & - & Renal 2/field \\
\hline Piocytes & - & 2/field \\
\hline Mucus & - & ++ \\
\hline Crystals & - & $\begin{array}{l}\text { Amorphous } \\
\text { phosphate + }\end{array}$ \\
\hline Spermatozoid & - & Absent \\
\hline
\end{tabular}

- Not performed due to intense hematuria. 
$\left(18,600\right.$ leukocytes $/ \mathrm{mm}^{3} ; 2,418$ rods $\left./ \mathrm{mm}^{3}\right)$ compatible with a leukemoid reaction. The mucous membranes became pearly and the animal presented typical signs of hypoxia, panting, tachycardiac, and prostrated.

Due to the presented picture, the blood transfusion was performed raising the VG to $28.1 \%$. Then, a urinary sample was collected by cystocentesis for uroculture and a bladder wash was performed for cytology. The uroculture was negative and the vesical lavage revealed scarce cellularity, characterized by typical and free urothelial cells, rare intact, and degenerated neutrophils, typical lymphocytes, and plasma cells among the lymphocytes, suggesting chronic cystitis. Orchiectomy was also performed as a treatment for prostatomegaly and excision biopsies of nodules near the foreskin, which were found to be cutaneous hemangiosarcoma.

Forty-eight hours after blood transfusion, the animal maintained leukocytosis by neutrophilia, with a left shift $(22,000$ total leukocytes $/ \mathrm{mm}^{3} ; 18,000 \mathrm{~mm}$ segmental neutrophils $/ \mathrm{mm}^{3}$, and $440 \mathrm{rods} / \mathrm{mm}^{3}$, respectively) which normalized 72 hours later, without any treatment. Since the hematuria presentation remained intense during the waiting for the test results, there was a significant drop in hematocrit (VG 21.4\%), even though a recent blood transfusion was performed. At physical examination, the mucous membranes were hypocolored, and although the animal remained at normorexia and alert, a second blood transfusion was performed after the blood compatibility test, to enable the performance of exploratory laparotomy and cystotomy for incisional biopsy of the bladder. During the cystotomy it was possible to observe the thickened and vascularized bladder wall, with normal elasticity, and absence of polyps and/or bladder masses.

The histopathology of the bladder sample showed a thickening of the muscle layer, hemorrhage, and diffuse hyperemia between the muscle fibers extending to the lamina propria. Numerous capillaries were intact and ruptured, when intact they were dilated and filled with RBCs, and when ruptured the RBCs were released into the lumen. In addition, there was a discrete infiltrate of lymphocytes and plasma cells on a multifocal slide with multifocal distribution, which is compatible with discrete multifocal lymphoplasmacyte hemorrhagic cystitis (Figure 2).

Treatment with prednisolone in immunosuppressive dose $(2 \mathrm{mg} / \mathrm{kg})$ was prescribed, which led to a gradual decrease until the absence of macroscopic hematuria in urinalysis, and consequent improvement of the hematological picture (VG $31 \%$ ) (Table 1). However, the owner interrupted the treatment without veterinary guidance, leading to the reappearance of intense macroscopic hematuria with a stinking odor and alkaline $\mathrm{pH}$, accompanied by a further drop in the hematocrit (VG 19.8\%) and reappearance of leukocytosis neutrophilia, with left regenerative deviation $(43,100$ total leukocytes $/ \mathrm{mm}^{3} ; 34,049$ segmental neutrophils $/ \mathrm{mm}^{3} ; 5,172$ rods $/ \mathrm{mm}^{3}$, respectively). New uroculture revealed growth of Escherichia coli. Even though the antibiotic therapy with Amoxicillin-Potassium Clavulanate $(22 \mathrm{mg} / \mathrm{kg}$, VO, IDB) was prescribed associated to prednisolone in immunosuppressive dose $(2 \mathrm{mg} / \mathrm{kg}, \mathrm{VO}, \mathrm{IDB})$, according to the antibiogram result, the patient did not present response to the treatment, which led to severe hematocrit drop (VG 7.5\%) and maintenance of leukocytosis.

The animal received a third blood transfusion after a compatibility test, and Azathioprine (dose $1 \mathrm{mg} / \mathrm{kg}$, orally, every 24 hours) was associated with the treatment. The animal died less than 24 hours after the initiation of the immunosuppressive medication, and the postmortem evaluation was not performed by choice of the tutors.
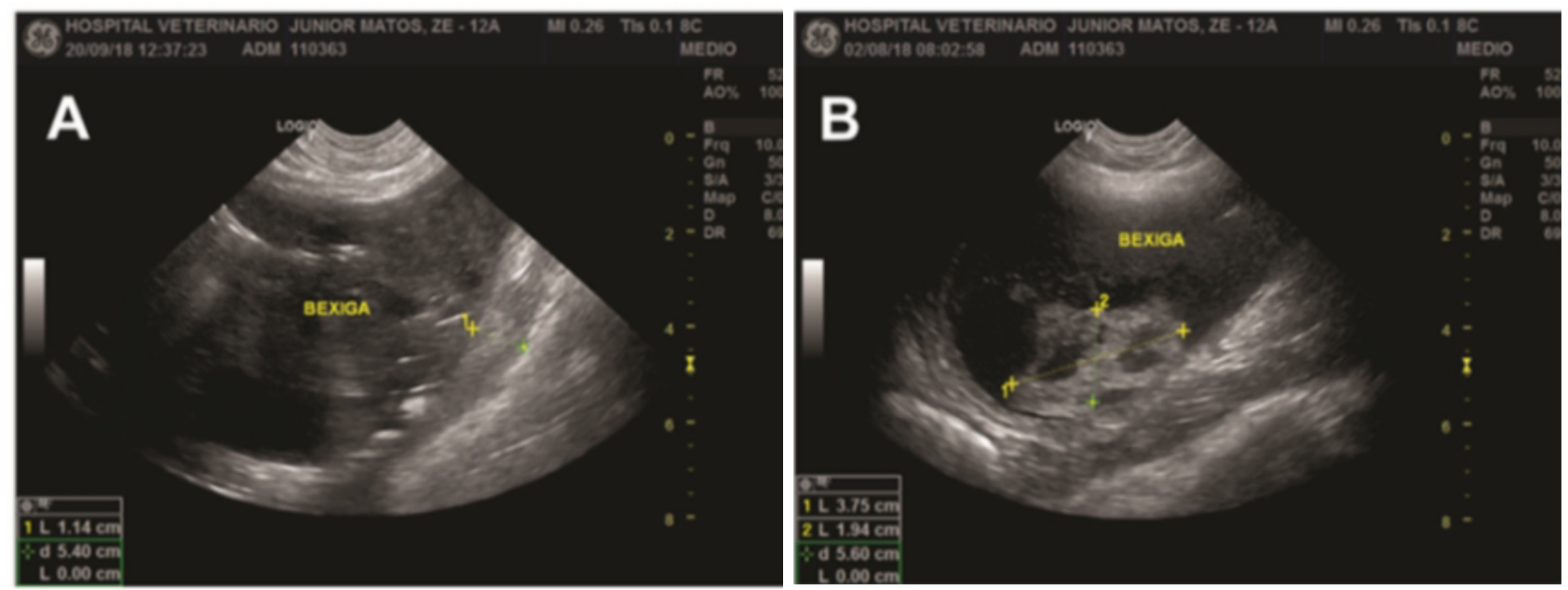

Source: Archive of the Diagnostic Imaging Sector of the Hospital Veterinário da Universidade Federal de Uberlândia (Veterinary Hospital of the Federal University of Uberlandia).

Figure 1. Ultrasound image of the canine bladder showing irregular, thick walls (A). The bladder content was echoic, with hyperechoic sediment, and acoustic shading in some points, dispersed and deposited in the dorsal wall in a pronounced amount, suggesting clots and cellularity (B). 


\section{DISCUSSION}

Anemia and persistent hematuria are striking features in this report. Although hematuria is a common clinical sign in diseases affecting the urinary system, severe hematuria leading to anemia is an uncommon condition (WESTROPP; DIBARTOLA, 2015; ADAMAMA-MORAITOU et al., 2017; BRESHEARS; CONFER, 2018), which highlights the case reported as rare. It should be noted that even in the presence of a neoplastic cause, with the exception of hemangiosarcoma, this is not usually severe (HOLT, 2008) to the extent of causing anemia with risk of death in a short period of time.

Although idiopathic renal hematuria, an uncommon and intermittent disease that usually affects young adult dogs with an average of 5 years old, is the disease with greater probability of leading to anemia (WESTROPP; DIBARTOLA, 2013), this was discarded because the patient did not present dysmorphic red blood cells (SILVA et al, 2014), hematic cylinders in any microscopically evaluated urine sample (MEUTEN, 2015), nor any significant macroscopic renal structural change was detected at ultrasound, associated with the presence of clots in the urinary bladder, which are suggestive of alterations in the lower urinary tract (COUTINHO LN, CRIVELLENTI, 2015).

Prostatic hyperplasia is also a common cause of hematuria in intact male dogs more than 5 years old, and its diagnosis can be confirmed by histopathology (MOTHEO, 2015). In the patient under study, although it may be involved, prostatic hyperplasia is definitely not a major cause of hematuria, since the reflux of red blood cells of prostatic origin is minimal even in these patients, and the semiologic characteristic of hematuria has always been bleeding during the whole urination period, and there is no observation at any time of drips in the intermictional periods and/or elimination of clots

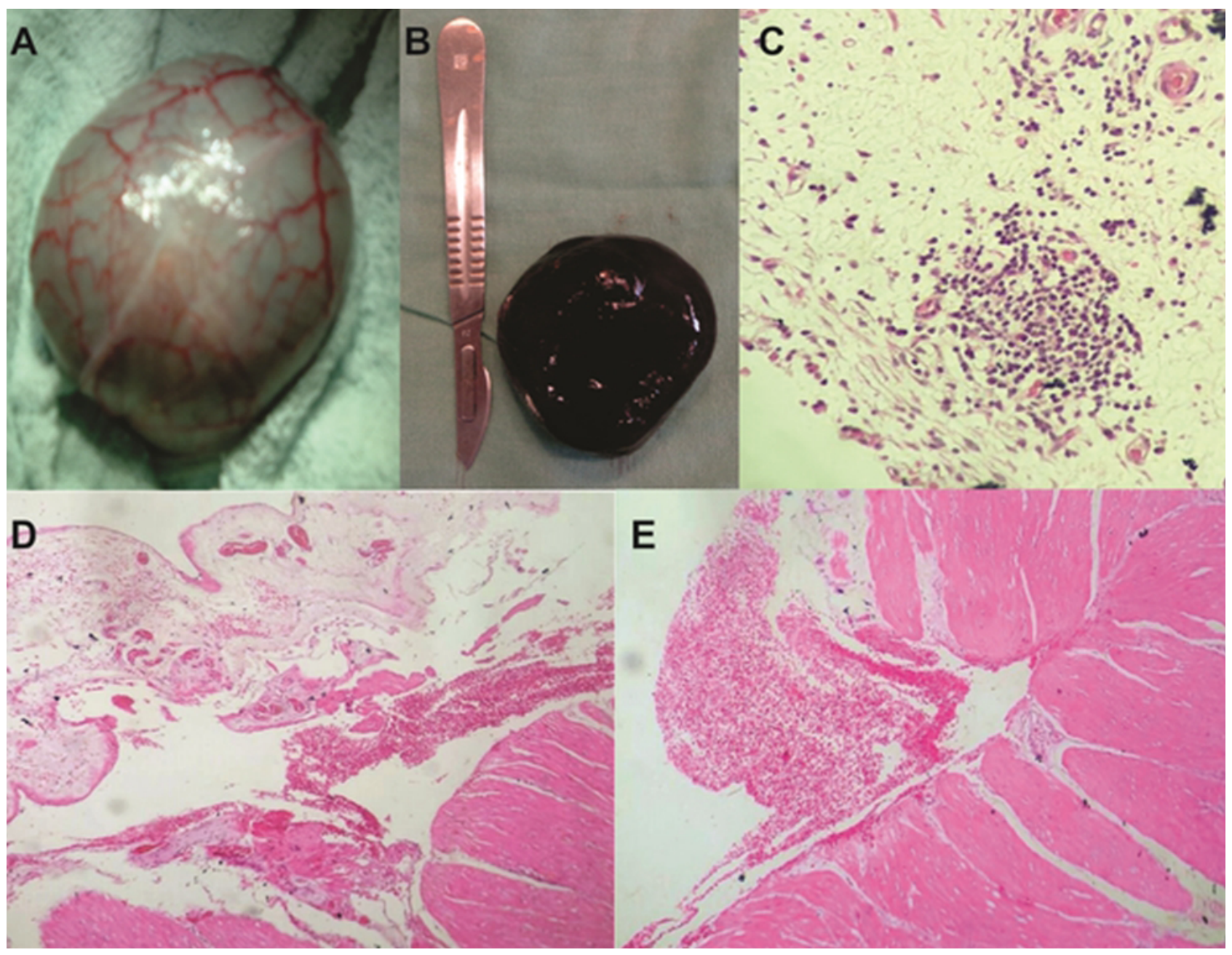

Source: Archive of the Sectors of Animal Pathology and Small Animal Surgery of the Hospital Veterinário da Universidade Federal de Uberlândia (Veterinary Hospital of the Federal University of Uberlandia).

Figure 2. (A) Macroscopic photo of the bladder during the cystotomy, showing the thickened and vascularized bladder wall, and absence of bladder masses or polyps. (B) Clot removed from the inside of the bladder. (C; D; E) Photomicrography of the bladder wall stained in H.E.n (D) Obj. 40x. Lamina propria with focal cluster of lymphocytes and plasma cells and a small number of leukocytes distributed in the fragment (arrow). (E) Obj. 10x. Bleeding between the muscle layer and the lamina propria (arrow), with moderate amount of red blood cells outside the vessels. (F) Obj. 10x extensive bleeding in the muscle layer (arrow). 
concentrated at the beginning of urination, which typically involves bleeding into the genital tract (CARVALHO, 2016).

The anemia presented in the first examination showed attributes of slightly regenerative anemia when the morphological characteristics of the red blood cells are considered, which is consistent with the expected in hemorrhagic anemia that is chronifying. Chronic bleeding initially leads to regenerative anemia, but chronic blood loss leads to reduced substrates for erythropoiesis, especially iron stores, resulting in the release of hypochromic and microcytic RBCs into the circulation, with a consequent decrease in MCV and HCMC. Persistent leukocytosis and thrombocytosis are also common features of chronic bleeding (VILLIERS; RISTIĆ, 2016).

The cytology examination through bladder washing and ultrasound suggested a chronic cystitis condition. Despite the cytology not suggestive of neoplasm, the fact of the patient being elderly, associated to the severe clinical picture and clinical signs similar to a report of bladder lymphoma in a dog (BENIGNI et al., 2006), the diagnosis of bladder neoplasm was only discarded with the result of the histopathology, that pointed a cystitis of chronic nature, with possible autoimmune origin.

Acute cystitis is common in dogs (WESTROPP; DIBARTOLA, 2015), although chronic and hemorrhagic cystitis is not frequent, with few cases already reported in the literature, especially without an underlying cause (FUENTEALBA; ILLANES, 2000; WALKER, 2018,). However, studies with histopathology of urinary lesions in dogs have described an occurrence of $20 \%$ to $35 \%$ of chronic cystitis, considered occasional findings, with higher occurrence in females (INKELMANN et al., 2012; SAPIN, et al., 2016).

Reports of hemorrhagic cystitis in dogs and humans in general are associated with bacterial infections or use of chemotherapy (BEST; FRY, 2013; UKWUEZE, 2015).

In humans, there are reports of various chronic cystitis, such as panmural and interstitial cystitis, some of which present a good clinical response to the use of corticoids, with significant resolving of urinary symptoms and improvement of cystoscopic characteristics, which suggests that some of them may have an autoimmune etiology (PACELLA et al., 2010; CERRUTO; D'ELIA; ARTIBANI, 2013; UEDA et al., 2016).

However, the presence of intact and ruptured capillaries both in the lamina propria and in the muscle layer is the most striking characteristic of the case in question and this finding is not similar to any type of chronic cystitis mentioned in the literature about dogs.

The patient in this report died after receiving three transfusions and several treatment attempts, with good initial response to the use of corticoids. This suggests that continuous use of corticoids with an adjusted dose in response to treatment, similar to that performed in other autoimmune diseases, could increase the quality and survival of patients with lymphoplasmacytic hemorrhagic cystitis, with the possibility of association with other immunosuppressants.

In cases of bladder malignancies, cystectomy surgery has been suggested as a treatment with satisfactory management of quality of life (ANDERSEN et al., 2012; HUPPES et al., 2016), as well as in humans with bladder pain syndrome / disabling interstitial cystitis not responsive to treatment. For this reason, we may consider it as an option for the treatment of patients with severe hemorrhagic cystitis with resistance to drug treatment.

Due to histopathological aspects and to the initial response to immunosuppressive drug treatment, we suggest that conditions like this may have an autoimmune origin and require further studies on possible underlying diseases such as leishmaniasis, systemic lupus erythematosus, and tumors.

\section{CONCLUSION}

Therefore, lymphoplasmacytic hemorrhagic cystitis in dogs is rare, with the present report being the first case reported in the consulted literature. Even after the diagnosis, the prognosis of the animal was unfavorable.

\section{REFERENCES}

ADAMAMA-MORAITOU, K.K. et al. Evaluation of dogs with macroscopic haematuria: a retrospective study of 162 cases (2003-2010). New Zealand veterinary journal, v. 65, n. 4, p. 204-208, 2017.

ANDERSEN, A. V. et al. Long-term experience with surgical treatment of selected patients with bladder pain syndrome/ interstitial cystitis. Scandinavian journal of urology and nephrology, v. 46, n. 4, p. 284-289, 2012.

BENIGNI, L. et al. Lymphoma Affecting The Urinary Bladder In Three Dogs And A Cat. Veterinary Radiology \& Ultrasound, v. 47, n. 6 , p. 592-596, 2006.
BERENT, A.C. et al. Endoscopic-guided sclerotherapy for renal-sparing treatment of idiopathic renal hematuria in dogs: 6 cases (2010-2012). Journal of the American Veterinary Medical Association, v. 242, n. 11, p. 15561563, 2013.

BEST, M.P.; FRY, D.R. Incidence of sterile hemorrhagic cystitis in dogs receiving cyclophosphamide orally for three days without concurrent furosemide as part of a chemotherapeutic treatment for lymphoma: 57 cases (2007-2012). Journal of the American Veterinary Medical Association, v. 243, n. 7, p. 1025-1029, 2013. 
BRESHEARS, M.A.; CONFER, A.W. O Sistema Urinário. In: ZACHARY, J.F. Bases Da Patologia Em Veterinária. 6. ed. Rio de Janeiro: Elsevier, 2018, Cap. 11, p. p 617-681.

CARVALHO, M.B. Semiologia do Sistema Urinário. In: FEITOSA, F.L.F. Semiologia Veterinária. A arte do Diagnóstico. Rio de Janeiro: Roca, 2016, p.351-366.

CERRUTO, M.A.; D'ELIA, C.; ARTIBANI, W. A case of eosinophilic cystitis in patients with abdominal pain, dysuria, genital skin hyperemia and slight toxocariasis. Archivio Italiano di Urologia e Andrologia, v. 85, n.2, p. 99-100, 2013.

COUTINHO LN; CRIVELLENTI LZ. Trato urinário inferior. In: FELICIANO M.A.R; CANOLA J.C; VICENTE W.R.R. Diagnóstico por Imagem em Cães e Gatos. São Paulo: MedVet. Cap. 13, pp. 442-467, 2015

FUENTEALBA, I.C.; ILLANES, O.G. Eosinophilic cystitis in 3 dogs. The Canadian Veterinary Journal, v. 41, n. 2, p. 130$131,2000$.

HOLT, P.E. Urological Disorders of The Dog and Cat. 1. ed. London. Manson Publishing, 2008.p. 124.

HUPPES, R. et al. Radical cystectomy and cutaneous ureterostomy in 4 dogs with trigonal transitional cell carcinoma: description of technique and case series. Veterinary Surgery, v. 46, n.1, p. 111-119, 2017.

INKELMANN, M. A. et al. Lesões do sistema urinário em 1.063 cães. Pesquisa Veterinária Brasileira, v. 32, n.8, p. 761 $771,2012$.

KANEKO, J. HARVEY, J.; BRUSS, M. Clinical Biochemistry of Domestic Animals. 6 ed. 2008. Academic Press.

MACDONALD, V.; DICKINSON, R. Hemorrhagic cystitis in a dog receiving carboplatin. Journal of the American Animal Hospital Association, v. 50, n. 1, p. 67-70, 2014.

MEUTEN, D. Avaliação e Interpretação Laboratorial do Sistema Urinário. In: THRAL, M.A et al. Hematologia e Bioquímica Clínica Veterinária. 2 ed. Rio de Janeiro: Roca, 2015. p.297-298.

MOTHEO, T.F. Teriogenologia. In: CRIVELLENTI, L.Z; BORINCRIVELLENTI, S. Casos de Rotina em Medicina Veterinária de Pequenos Animais. São Paulo: Medvet Livros, 2015. p.794.

PACELLA, M. et al. Interstitial cystitis with plasma cell bladder infiltration: Case report and literature review. Archivio Italiano di Urologia e Andrologia, v. 82, n. 2., 122124, 2010.

SAPIN, C.D.F. et al. Anatomo-pathological and epidemiological analysis of urinary tract lesions in dogs. Ciência Rural, v. 46, n. 8, p. 1443-1449, 2016.

SCHALM'S, O.W.; FELDMAN, B.F.; ZINKL, J.G; JAIN, N.C. Veterinary Hematology. 5ed. Philadelphia : Lippincott Williams \& Wilkins, 2020.

SILVA, G.E.; TEIXEIRA, A.C.; VERGNA, J.G.; SALGADO-FILHO, N.; CRIVELLENTTI, L.Z.; COSTA, R.S.; DANTAS, M. A novel case report of sickle cell disease-associated immunoglobulin $A$ nephropathy: The diagnostic value of erythrocyte dysmorphism evaluation. International Journal of Clinical and Experimental Medicine, v. 7, n. 6, p. 1619, 2014.

UEDA, Y. et al. Interstitial cystitis associated with primary Sjögren's syndrome successfully treated with a combination of tacrolimus and corticosteroid: a case report and literature review. Modern rheumatology, v. 26, n.3, p. 445-449, 2016.

VILLIERS, E.; RISTIĆ, J. Bsava manual of canine and feline clinical pathology. British small animal veterinary association. 2ed. British Small Animal Veterinary Association, 2016.pp. 579.

UKWUEZE, C. S. Successful Medical Treatment of Haemorrhagic Cystitis in a Dog. International Journal of Medical and Pharmaceutical, v. 3, n. 5, p. 127-131, 2015.

WALKER, M.A. Struvite urolithiasis with eosinophilic polypoid cystitis in a shih tzu dog. The Canadian Veterinary Journal, v. 59, n. 2, p. $181,2018$.

WESTROPP, J.L.; DIBARTOLA, S.P. Manifestações Clínicas Das Doenças Do Trato Urinário. 5. ed. In: NELSON, R.W.; COUTO, C.G. Medicina Interna De Pequenos Animais. Rio De Janeiro: Elsevier, 2015, cap. 41, p. 1838-1858. 